Article

\title{
Ultrasound-Assisted Extraction of Polyphenols from Crude Pollen
}

\author{
Mircea Oroian *, Florin Ursachi and Florina Dranca \\ Faculty of Foond Engineering, Stefan cel Mare University of Suceava, 720229 Suceava, Romania; \\ f.ursachi@yahoo.com (F.U.); florina.dranca@usm.ro (F.D.) \\ * Correspondence: m.oroian@fia.usv.ro; Tel.: +40-744-524-872
}

Received: 28 March 2020; Accepted: 14 April 2020; Published: 16 April 2020

\begin{abstract}
The aim of this study was to evaluate the extraction efficiency of polyphenols from crude pollen by an ultrasonic process. Prior to the polyphenols extraction, the crude pollen was defatted. The extraction from defatted pollen was carried out by varying four extraction parameters: ultrasonic amplitude $(20 \%, 60 \%$ and $100 \%)$, solid/liquid ratio $(10 \mathrm{~g} / \mathrm{L}, 20 \mathrm{~g} / \mathrm{L}$ and $30 \mathrm{~g} / \mathrm{L})$, temperature $(35,50$ and $65^{\circ} \mathrm{C}$ ) and time (10, 20 and $\left.30 \mathrm{~min}\right)$. The extracts were analyzed in terms of extraction yield (\%), total phenolic content (TPC) and total flavones content (TFC). The extracted oil was analyzed in terms of fatty acids composition; myristic acid $\left(159.1 \mu \mathrm{g} \times \mathrm{g}^{-1}\right)$ and cis-14-pentadecenoic acid $\left(106.6 \mu \mathrm{g} \cdot \mathrm{g}^{-1}\right)$ were found in the highest amount in the pollen oil. The optimum conditions of extraction were determined and were, as follows: $100 \%$ amplitude of ultrasonic treatment, $30 \mathrm{~g} / \mathrm{L}$ solid/liquid ratio, $40.85^{\circ} \mathrm{C}$ and $14.30 \mathrm{~min}$, which led to the extraction of $366.1 \mathrm{mg} \mathrm{GAE} / \mathrm{L}$ of TPC and $592.2 \mathrm{mg} \mathrm{QE} / \mathrm{g}$ of TFC, and also to an extraction yield of $1.92 \%$.
\end{abstract}

Keywords: pollen; polyphenol; extraction; ultrasonic

\section{Introduction}

Pollen is a fine yellow-red powder-like material produced by flowering plants and is gathered by bees [1]; it results from the agglutination of flower pollen, the nectar of honey and the salivary substances from the bees [2]. The chemical composition of bee pollen depends on several factors, such as plant source, geographical origin, seasonal conditions and bee activities [3,4]. The main constituents of pollen are: proteins [2,4], carbohydrates [4,5], lipids [4,5], amino acids [4,5], polyphenols [4,6,7] and carotenoids [4,7]. Pollen composition, in mean concentrations, is made up of sugars $(40 \%)$, protein $(23 \%)$, including amino acids $(10 \%)$ and lipids (10\% reported in dry weight). The main amino acids contained by pollen are methionine, lysine, threonine, histidine, leucine, isoleucine, valine, phenylalanine and tryptophan, the main sugars are fructose (approx. 19\%), glucose (approx. 15\%) and sucrose $(7 \%)$, while the main fatty acids are linoleic (18:2n-6), $\alpha$-linolenic (18:3n-3) and palmitic (16:0) acids $[2,4,5]$. The color of pollen is given by the presence of the flavonoids and carotenoids (lutein, $\beta$-cryptoxanthin and $\beta$-carotene) [8].

Ultrasound-assisted extraction is a key technique that can be considered a green technology for the extraction of polyphenols from the different matrix. The extraction based on ultrasound has high reproducibility, requires lower quantities of solvents, simplifies the manipulation, eliminates the high quantities of waste water and the final extracts have higher purity [9-11]. The increase of extraction efficiency, alongside the reduction of the extraction time, is determined by two mechanisms: ultrasonic cavitation and mechanical mixing effect. The ultrasonic extraction mechanism involves the following processes: fragmentation, erosion, effect, sonoporation, local shear stress, and detexturation [12]. During the propagation of the ultrasounds into the solvent, the molecules' speed increases and cell disruption appears when the cavitation bubbles collapse on the cell surface $[13,14]$. 
Ultrasound-assisted extraction of polyphenols from crude pollen was used by Yang et al. [15] and Wu et al. [16]. Yang et al. [15] used ultrasonic and ball-milling treatment to improve the extraction of bioactive compounds from rose bee pollen, while Wu et al. [16] used ultrasonic and high shear technique for improving the extraction of amino acids, fatty acids, protein, crude fat, reducing sugar, $\beta$-carotene, calcium, iron, zinc and selenium, respectively.

To our knowledge, there are no other studies related to the optimization of ultrasound-assisted extraction of polyphenols from crude pollen. The aim of this study was to investigate the ultrasonic extraction of bioactive compounds from bee pollen using a direct ultrasound-assisted extraction; the extraction parameters (ultrasonic amplitude, solid/liquid ratio, temperature) and time-input parameters were modeled using the Box-Behnken design. The extracts were analyzed in terms of extraction yield (\%), total phenolic content (TPC) and total flavones content (TFC), and the fatty acid composition of pollen oil was determined using GC-MS. The extract obtained in optimal extraction conditions was analyzed in terms of individual phenolics composition (gallic acid, protocatechuic acid, vanillic acid, $p$-hydroxybenzoic acid, chlorogenic acid, caffeic acid, $p$-coumaric acid, rosmarinic acid, myricetin, quercetin, luteolin and kaempferol).

\section{Materials and Methods}

Crude pollen was purchased from a local beekeeper from Suceava County, Romania. The crude pollen was harvested in the summer of 2019 and was polyfloral. The samples were packed and stored at $-20{ }^{\circ} \mathrm{C}$ until further analysis. The extraction of a lipid fraction from the pollen sample was performed by the Soxhlet method using pure hexane: $10 \mathrm{~g}$ of pollen was extracted with $100 \mathrm{~mL}$ of hexane into a Soxhlet apparatus, and the solvent was recirculated 5 times. Five batches were extracted as $10 \mathrm{~g}$ of crude pollen. The mixture of solvent and oil was separated using a rotary evaporator under vacuum at $65{ }^{\circ} \mathrm{C}$. The defatted pollen was used for the extraction of polyphenols, while the lipid fraction was analyzed in terms of fatty acids composition.

Methanol, $\mathrm{AlCl}_{3}$, Folin-Ciocalteau reagent, sodium carbonate, gallic acid, protocatechuic acid, p-hydroxybenzoic acid, caffeic acid, vanillic acid, chlorogenic acid, p-coumaric acid, rosmarinic acid, myricetin, luteolin, quercetin and kaempferol were purchased from Sigma-Aldrich (Taufkirchen, Germany).

\subsection{Ultrasonic Extraction Procedure}

The sample was placed in an ultrasonic bath model Ti-H-15 (Elma, Singen, Germany) at $25 \mathrm{kHz}$ and a maximum power of $100 \mathrm{~W}$. The extractions were carried according to the parameters presented in Table 1 , using in each extract procedure $30 \mathrm{~mL}$ of solvent $(80 \%(\mathrm{v} / \mathrm{v})$ methanol).

Table 1. Actual and coded values of experimental design.

\begin{tabular}{cccc}
\hline \multirow{2}{*}{ Independent Variables } & \multicolumn{3}{c}{ Coded Values } \\
\cline { 2 - 4 } & $\mathbf{- 1}$ & $\mathbf{0}$ & $\mathbf{1}$ \\
\hline Ultrasonic amplitude $(\%)-X_{1}$ & 20 & 60 & 100 \\
Solid liquid ratio & 10 & 20 & 30 \\
Temperature $\left({ }^{\circ} \mathrm{C}\right)-X_{3}$ & 35 & 50 & 65 \\
Time $(\min )-X_{4}$ & 10 & 20 & 30 \\
\hline
\end{tabular}

\subsection{Methods}

\subsubsection{Total Phenolic Content (TPC)}

The method used for the determination of total phenolic content was described by Escriche and Juan-Borras [17]. $100 \mu \mathrm{L}$ of each extract of pollen plus $1900 \mu \mathrm{L}$ distilled water were placed in a glass tube, and then the solution was oxidized by adding $100 \mu \mathrm{L}$ of Folin-Ciocalteau reagent. After exactly $2 \mathrm{~min}, 800 \mu \mathrm{L}$ of $5 \%$ sodium carbonate (w/v) was added. This solution was maintained in a water bath at $40^{\circ} \mathrm{C}$ for $20 \mathrm{~min}$, and then the tube was rapidly cooled with crushed ice to stop the reaction. 
The absorbance of the solutions was recorded at $760 \mathrm{~nm}$. The TPC results were expressed as $\mathrm{mg}$ gallic acid equivalent/L (mg GAE/L), and all the determination were done in triplicate using methanol as blank.

\subsubsection{Total Flavone Content (TFC)}

The method used for the analysis of total flavone content was described by Popova et al. [18]. A $2 \mathrm{~mL}$ aliquot of extract, $20 \mathrm{~mL}$ methanol and $1 \mathrm{~mL} \mathrm{5 \%} \mathrm{AlCl}_{3}$ in methanol (w/v) were mixed in a volumetric flask, and the volume was made up to $50 \mathrm{~mL}$ with methanol. The mixture was left to rest for $30 \mathrm{~min}$. The absorbance of the solutions was recorded at $425 \mathrm{~nm}$. The TFC results were expressed as $\mathrm{mg}$ quercetin equivalent/L (mg QE/L), and all the determination were done in triplicate using methanol as blank.

\subsubsection{Individual Phenolics Separation and Detection}

The phenolic extracts were analyzed using a high-performance liquid chromatography (HPLC) instrument (Shimadzu, Kyoto, Japan) coupled with a diode array detector. The separation was carried out on a Zorbax SP-C18 column, with $150 \mathrm{~mm}$ length, $4.6 \mathrm{~mm}$ i.d., $5 \mu \mathrm{m}$-diameter particle and thermostated at $25^{\circ} \mathrm{C}$. The sample volume injection was $10 \mu \mathrm{L}$. For the separation of phenolics, we used two mobile phases: A (0.1\% acetic acid in water) and B (acetonitrile), respectively, using the following gradient: $\min 0$ - A 100\%, min 6.66 - B 5\%, min 66.66 - B 40\% and $\min 74-\mathrm{B} 80 \%$ [19-21]. The solvent flow rate was $1 \mathrm{~mL} / \mathrm{min}$. The phenolics (at $280 \mathrm{~nm}$ for gallic acid, protocatechuic acid, vanillic acid and $p$-hydroxybenzoic acid; and $320 \mathrm{~nm}$ for chlorogenic acid, caffeic acid, $p$-coumaric acid, rosmarinic acid, myricetin, quercetin, luteolin and kaempferol) were determined based on the retention times and quantified based on their calibration curves (all the curves had $\mathrm{R}^{2}$ higher than 0.98). For the methanoic extract, the phenolics were determined using the retention times and their nature was confirmed by their absorption spectra.

\subsubsection{GC Analysis of Fatty Acids Methyl Esters}

Fatty acid derivation was made based on the method described by Dulf [22]. The separation of the fatty acids methyl esters was carried out on a Shimadzu GC-MS instrument (GC MS-QP 2010 Plus, Shimadzu, Japan) equipped with an AOC-01 auto-injector that was used to perform the gas chromatographic-mass spectrometric analyses. The fatty acid methyl esters were separated using a SUPELCOWAX 10 column $(60 \mathrm{~m} \times 0.25 \mathrm{~mm}$ i.d., $0.25 \mu \mathrm{m}$ film thickness; Supelco Inc., Bellefonte, PA, USA). The initial oven temperature was $140{ }^{\circ} \mathrm{C}$ and was increased to $220^{\circ} \mathrm{C}$ at a rate of $7{ }^{\circ} \mathrm{C} / \mathrm{min}$ and then held at this temperature for $23 \mathrm{~min}$. The flow rate of the carrier gas $(\mathrm{He})$ and the split ratio were $0.8 \mathrm{~mL} / \mathrm{min}$ and $1: 24$, respectively. The injector temperature was $210^{\circ} \mathrm{C}$. The mass spectrometer interface and source temperatures were 250 and $200{ }^{\circ} \mathrm{C}$, respectively. Electroionisation mass spectra were recorded in the positive ion mode at $70 \mathrm{eV}$ and with a mass range of $\mathrm{m} / \mathrm{z} 22-395$. Each measurement was made in triplicate. The injection volume was set at $1 \mu \mathrm{L}$. Identification of FAMEs was done by comparing their retention times with those of known standards (37 component FAME Mix, Restek, Bellefonte, PA, USA, 35077) and the resulting mass spectra to the ones from our database (NIST MS Search 2.0).

\subsubsection{FT-IR}

Fourier-transform infrared spectroscopy (FT-IR) analysis was made using a Nicolet i-20 spectrophotometer (Thermo Scientific, Karlsruhe, Dieselstraße, Germany). The spectra were recorded in transmission mode using the Attenuated total reflectance (ATR) system within the wave number range of $4000-400 \mathrm{~cm}^{-1}$ at a resolution of $4 \mathrm{~cm}^{-1}$. SpectraGryph-spectroscopy software (Version 1.2.11, Dr. Friedrich Menges, Germany, www.effemm2.de) was used to display the spectra. The samples (crude pollen, defatted pollen, pollen extract and pollen oil) were placed on the ATR crystal, and the spectra were recorded in triplicate. 


\subsubsection{Experimental Design and Statistical Analysis}

The Box-Behnken design with four factors was used for the modeling of the pollen extraction process (Table 1). The input variables were ultrasonic amplitude, solid/liquid ratio, temperature and time and the output variables were extraction yield, TPC and TFC. Design expert 16 (trial version, StatEase, minneapolis, MN, USA) was used for the experimental design. A second-order polynomial response was used for the pollen extraction process modeling:

$$
y=b_{0}+\sum_{i=1}^{n}\left(b_{i} x_{i}\right)+\sum_{i=1}^{n}\left(b_{i i} x_{i i}^{2}\right)+\sum_{i j=1}^{n}\left(b_{i j} x_{i} x_{j}\right)
$$

where $y$ is the predicted response (extraction yield, TFC or TPC), $x_{i}$ stands for the coded levels of the design variable (ultrasonic amplitude, solid/liquid ratio, temperature and time), $b_{0}$ is a constant, $b_{i}=$ linear effects, $b_{i i}=$ quadratic effects and $b_{i j}=$ interaction effects.

\section{Results}

The influence of ultrasonic amplitude, solid/liquid ratio, temperature and time on the extraction yield, TPC and TFC is presented in Table 2.

\subsection{Influence of Ultrasonic Amplitude}

The ultrasonic amplitude had positively influenced the extraction yield $(p<0.001)$, TPC $(p<0.001)$ and TFC $(p<0.001)$; with the increase of the amplitude all three parameters increased statistically significantly. The increase of the ultrasonic amplitude led to an increase in the cavitation effects of the ultrasonics. Our findings were in agreement with those reported for the polyphenol extraction from Nepheliuml appaceum [23], grape seeds [24], mashed tea leaves [25] and Acer truncatum leaves [26]. The ultrasound waves $(24-50 \mathrm{kHz})$ determined an increase in the extraction efficiency due to the cavitation process, which involved the formation and collapse of the cavitation bubbles produced in the extraction media during wave propagation. The implosion of the bubbles generated microjets and solvent flows, which in turn led to the next phenomena: cell rupture and mass transfer. These two phenomena resulted in an increase in the release of polyphenols from the matrix into the solvent.

\subsection{Influence of Solid/Liquid Ratio}

The solid/liquid ratio had a positive influence on the extraction yield $(p<0.001)$, TPC $(p<0.001)$ and $\operatorname{TFC}(p<0.001)$; it was found that with the increase of the solid/liquid ratio all three parameters increased statistically significantly. In our study, the suitable solid/liquid ratio was $30 \mathrm{~g} / \mathrm{L}$. The knowledge regarding the optimum solid/liquid ratio is important from the economic point of view, as well as for enhancing the extraction efficiency and its outcomes. The effect of this parameter was attributed to the possibility that the reduced mixture density attained as a result of the higher solvent-to-material ratio increased the ultrasound wave propagation speed while reducing the effect of attenuation of ultrasounds and increasing the transfer of energy/distance covered by wave/time [27,28]. Our findings were in agreement with those reported by Setyaningsih et al. [29] for the extraction of polyphenols from rice grains, De Oliveira et al. [30] for the extraction of hibalactone in Hydrocotyle umbellata subterraneous parts and Pavlic et al. [31] for the extraction of polyphenols from peppermint.

\subsection{Influence of Extraction Temperature}

The influence of temperature on the extraction yield, TPC and TFC are presented in Table 2. As can be observed, the temperature of extraction influenced statistically significantly only the extraction yield, while in the case of TPC and TFC, the influence was not statistically significant. The increase of the extraction yield with the temperature might be because of the high solubility of different extractible compounds from pollen into methanol. The increase of temperature may increase the extraction efficiency 
due to the disruption of the cellular matrix structure which leads to the improvement of the solubility of polyphenols from the matrix and the mass transfer to the solvent [32]. The increase of temperature may decrease the surface tension and the viscosity, which will promote the solvent penetration into the matrix and improve the extraction process $[33,34]$. Our results were in agreement with those reported in the case of polyphenol extraction from wild sage [35], bioactive compounds from aromatic plants [36], polyhenols and anthocyanin from eggplant [14,37] and polyphenols from propolis [21].

\subsection{Influence of Extraction Time}

Table 2 shows the influence of time on the extraction yield, TPC and TFC. As can be observed, the extraction time had no statistically significant influence on the extraction, as only TPC showed an improvement of the concentration by $3.7 \%$, while in the case of TFC, the concentration had decreased by $14.3 \%$. The decrease in the TFC concentration might be because of the thermo-instability of the flavones [38]. The extraction yield was similar for all extraction times, which was due to the low particle diameter of the pollen sample $(<125 \mu \mathrm{m})$, as we found that $10 \mathrm{~min}$ were enough to reach the maximum efficiency of the extraction, during which the sonication and the solvent penetrated the cell membrane and improved the mass transfer rate into the solvent $[39,40]$.

\subsection{Extraction Modeling}

Response surface methodology was implemented via a three-block experiment Box-Behnken design to model the ultrasound-assisted extraction of bioactive compounds from crude pollen and optimize the extraction yield, TPC and TFC.

\subsection{Extraction Yield}

Experimental data for extraction yield, total phenolic content (TPC) and total flavones content (TFC) were fitted to quadratic equations using a Box-Behnken design, and the equations obtained for these parameters are presented below:

$$
\begin{aligned}
\text { Extraction yield }= & 1.24+0.028 \cdot \mathrm{X}_{1}+0.62 \cdot \mathrm{X}_{2}+0.03 \cdot \mathrm{X}_{3}+0.002 \cdot \mathrm{X}_{4}+0.01 \cdot \mathrm{X}_{1}^{2}+0.02 \cdot \mathrm{X}_{2}^{2} \\
+ & 0.02 \cdot \mathrm{X}_{3}^{2}-0.01 \cdot \mathrm{X}_{4}^{2}+0.01 \cdot \mathrm{X}_{1} \cdot \mathrm{X}_{2}-0.02 \cdot \mathrm{X}_{1} \cdot \mathrm{X}_{3}+0.01 \cdot \mathrm{X}_{1} \cdot \mathrm{X}_{4} \\
- & 0.003 \cdot \mathrm{X}_{2} \cdot \mathrm{X}_{3}+0.001 \cdot \mathrm{X}_{2} \cdot \mathrm{X}_{4}+0.02 \cdot \mathrm{X}_{3} \cdot \mathrm{X}_{4} \\
\mathrm{TPC}=271.4+ & 36.9 \cdot \mathrm{X}_{1}+100.1 \cdot \mathrm{X}_{2}+7.7 \cdot \mathrm{X}_{3}+4.2 \cdot \mathrm{X}_{4}-19.9 \cdot \mathrm{X}_{1}^{2}-20.9 \cdot \mathrm{X}_{2}^{2}-36.9 \cdot \mathrm{X}_{3}^{2} \\
& -14.7 \cdot \mathrm{X}_{4}^{2}+27.4 \cdot \mathrm{X}_{1} \cdot \mathrm{X}_{2}-1.4 \cdot \mathrm{X}_{1} \cdot \mathrm{X}_{3}-11.5 \cdot \mathrm{X}_{1} \cdot \mathrm{X}_{4}-10.6 \cdot \mathrm{X}_{2} \cdot \mathrm{X}_{3} \\
& -2.1 \cdot \mathrm{X}_{2} \cdot \mathrm{X}_{4}+5.2 \cdot \mathrm{X}_{3} \cdot \mathrm{X}_{4} \\
\mathrm{TFC}=395.5- & 47.2 \cdot \mathrm{X}_{1}+175.3 \cdot \mathrm{X}_{2}-18.7 \cdot \mathrm{X}_{3}-29.1 \cdot \mathrm{X}_{4}+34.9 \cdot \mathrm{X}_{1}^{2}-29.6 \cdot \mathrm{X}_{2}^{2}-9.9 \cdot \mathrm{X}_{3}^{2} \\
& -14.5 \cdot \mathrm{X}_{4}^{2}+30.8 \cdot \mathrm{X}_{1} \cdot \mathrm{X}_{2}+15.2 \cdot \mathrm{X}_{1} \cdot \mathrm{X}_{3}+36.0 \cdot \mathrm{X}_{1} \cdot \mathrm{X}_{4}-44.7 \cdot \mathrm{X}_{2} \cdot \mathrm{X}_{3} \\
& -7.7 \cdot \mathrm{X}_{2} \cdot \mathrm{X}_{4}+31.8 \cdot \mathrm{X}_{3} \cdot \mathrm{X}_{4}
\end{aligned}
$$

The statistical analysis results of the three parameters using the experimental data are presented in Table 3. The second-order polynomial response surface model was used based on its adequacy to the experimental data. The statistical parameters $R^{2}$, adj- $R^{2}$, coefficient of variance, F-value and $p$-values were used to check the suitability of the selected model. The regression coefficient $\left(\mathrm{R}^{2}\right)$ for extraction yield, TPC and TFC were higher than 0.93 , which means that the equation had a high capacity to closely depict the predicted values to the experimental ones. The models of the studied parameters had higher F-values (534.7 for extraction yield, 11.63 for TPC and 13.73 for TFC, respectively) and low $p$-values (for all parameters the $p$-value was lower than 0.0001 ), which confirm the validity of the proposed model for the prediction of the parameters in function of the extraction conditions. Exactness and trustworthiness of the experiments were analyzed through the coefficient of variance. The low coefficient of variance (1.99 for extraction yield, 13.1 for TPC and 12.50 for TFC) showed good accuracy and consistency of the experiments. 
Table 2. Analysis of variance of extraction parameter influence on total phenolic content (TPC), total flavonoid content (TFC) and extraction yield.

\begin{tabular}{|c|c|c|c|c|c|c|c|c|c|c|c|c|c|c|c|c|}
\hline \multirow{2}{*}{ Parameter } & \multicolumn{3}{|c|}{ Ultrasonic Amplitude (\%) } & \multirow{2}{*}{$\begin{array}{c}\text { F } \\
\text { Value }\end{array}$} & \multicolumn{3}{|c|}{ Solid Liquid Ratio (g/L) } & \multirow{2}{*}{$\begin{array}{c}\mathbf{F} \\
\text { Value }\end{array}$} & \multicolumn{3}{|c|}{ Temperature $\left({ }^{\circ} \mathrm{C}\right)$} & \multirow{2}{*}{$\begin{array}{c}\text { F } \\
\text { Value }\end{array}$} & \multicolumn{3}{|c|}{ Time (min) } & \multirow{2}{*}{$\begin{array}{c}\text { F } \\
\text { Value }\end{array}$} \\
\hline & 20 & 60 & 100 & & 10 & 20 & 30 & & 35 & 50 & 65 & & 10 & 20 & 30 & \\
\hline Extraction yield (\%) & $1.23^{c}$ & $1.25^{b}$ & $1.29^{a}$ & $15.4^{* * *}$ & $0.64^{\mathrm{c}}$ & $1.25^{b}$ & $1.89^{\mathrm{a}}$ & $7439 * * *$ & $1.24^{b}$ & $1.24^{b}$ & $1.30^{\mathrm{a}}$ & $14.3^{* *}$ & $1.25^{\mathrm{a}}$ & $1.27^{\mathrm{a}}$ & $1.26^{\mathrm{a}}$ & $0.08^{\mathrm{ns}}$ \\
\hline TPC (mg GAE/L) & $221^{b}$ & $222^{b}$ & $277^{\mathrm{a}}$ & $17.5^{* * *}$ & $164^{\mathrm{c}}$ & $233^{b}$ & $323^{a}$ & $128^{* * *}$ & $216^{\mathrm{a}}$ & $250^{\mathrm{a}}$ & $254^{\mathrm{a}}$ & $0.75^{\mathrm{ns}}$ & $238^{a}$ & $244^{\mathrm{a}}$ & $247^{a}$ & $0.23^{\mathrm{ns}}$ \\
\hline $\mathrm{TFC}(\mathrm{mg} \mathrm{QE} / \mathrm{L})$ & $346^{a}$ & $359^{a}$ & $441^{\mathrm{b}}$ & $11.4^{* *}$ & $197^{c}$ & $402^{b}$ & $547^{a}$ & $157^{* * *}$ & $397^{a}$ & $389^{a}$ & $360^{a}$ & $1.78^{\mathrm{ns}}$ & $406^{\mathrm{a}}$ & $392^{a}$ & $348^{a}$ & $4.34^{\mathrm{ns}}$ \\
\hline
\end{tabular}

GAE, gallic acid equivalent; $\mathrm{QE}$, quercetin equivalent, $\mathrm{ns}-p>0.05, * p<0.05,{ }^{* *} p<0.01,{ }^{* * *} p<0.001$; a-c Different letters in the same column indicate significant differences among samples $(p<0.05)$

Table 3. ANOVA analysis of model response for extraction yield, total phenolic content and total flavone content (TFC).

\begin{tabular}{cccccccc}
\hline \multirow{2}{*}{ Source } & \multirow{2}{*}{ DF } & \multicolumn{2}{c}{ Extraction yield $(\%)$} & \multicolumn{2}{c}{ TPC $(\mathbf{m g}$ GAE/L) } & \multicolumn{2}{c}{ TFC (mg QE/L) } \\
\cline { 3 - 8 } & & F-Value & $p$-Value & F-Value & $p$-Value & F-Value & $p$-Value \\
\hline Model & 14.0 & 534.7 & $<0.0001$ & 11.63 & $<0.0001$ & 13.73 & $<0.0001$ \\
$\mathrm{X}_{1}$ & 1.00 & 15.4 & 0.0015 & 17.52 & 0.0009 & 11.40 & 0.0045 \\
$\mathrm{X}_{2}$ & 1.00 & 7439 & $<0.0001$ & 128.2 & $<0.0001$ & 157.3 & $<0.0001$ \\
$\mathrm{X}_{3}$ & 1.00 & 14.3 & 0.0020 & 0.75 & 0.3998 & 1.78 & 0.2035 \\
$\mathrm{X}_{4}$ & 1.00 & 0.08 & 0.7794 & 0.23 & 0.6390 & 4.34 & 0.0559 \\
$\mathrm{X}_{12}$ & 1.00 & 0.44 & 0.5187 & 2.74 & 0.1198 & 3.36 & 0.0881 \\
$\mathrm{X}_{13}$ & 1.00 & 2.78 & 0.1175 & 3.04 & 0.1030 & 2.42 & 0.1420 \\
$\mathrm{X}_{14}$ & 1.00 & 5.53 & 0.0339 & 9.43 & 0.0083 & 0.27 & 0.6091 \\
$\mathrm{X}_{23}$ & 1.00 & 1.64 & 0.2207 & 1.50 & 0.2413 & 0.58 & 0.4577 \\
$\mathrm{X}_{24}$ & 1.00 & 0.57 & 0.4622 & 3.21 & 0.0946 & 1.62 & 0.2241 \\
$\mathrm{X}_{34}$ & 1.00 & 1.60 & 0.2265 & 0.01 & 0.9273 & 0.40 & 0.5390 \\
$X_{1}^{2}$ & 1.00 & 0.18 & 0.6781 & 0.56 & 0.4661 & 2.21 & 0.1590 \\
$X_{2}^{2}$ & 1.00 & 0.06 & 0.8074 & 0.48 & 0.4981 & 3.40 & 0.0864 \\
$X_{3}^{2}$ & 1.00 & 0.01 & 0.9110 & 0.02 & 0.8946 & 0.10 & 0.7547 \\
$X_{4}^{2}$ & 1.00 & 3.09 & 0.1005 & 0.11 & 0.7398 & 1.72 & 0.2112 \\
$\mathrm{R}^{2}$ & & 0.99 & & 0.93 & & 0.93 & \\
Adj-R ${ }^{2}$ & & 0.98 & & 0.84 & & 0.86 & \\
CV\% $^{2}$ & & 1.99 & & 13.1 & & 12.50 & \\
Adeq.Pre & & 72.6 & & 13.62 & & 12.84 & \\
\hline
\end{tabular}

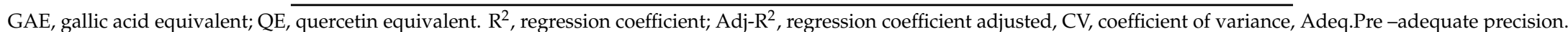




\subsection{Optimization of Extraction Parameters and Validation of the Models}

A desirability function approach was used to study the adequacy, and the optimum conditions were determined and were as follows: $100 \%$ amplitude of ultrasonic treatment, $30 \mathrm{~g} / \mathrm{L}$ solid/liquid ratio, $40.85^{\circ} \mathrm{C}$ and $14.30 \mathrm{~min}$. The extraction under optimum conditions reached $366.1 \mathrm{mg} \mathrm{GAE} / \mathrm{L}$ of TPC, $592.2 \mathrm{mg} \mathrm{QE} / \mathrm{g}$ of TFC and a 1.92\% extraction yield.

\subsection{Composition of Individual Phenolics}

Table 4 presents the concentrations of twelve phenolic compounds determined in the pollen extract (obtained at an ultrasonic amplitude of $100 \%$, solid/liquid ratio of $30 \mathrm{~g} / \mathrm{L}, 50{ }^{\circ} \mathrm{C}$ and 20 min extraction time). Figure 1 presents a typical chromatogram for a mixture of twelve phenolics and the methanoic pollen extract composition. In our study, there were determined the aglycone forms of the phenolics, but not the flavonoids glycosides and methylated flavonoids. As can be observed, the main flavonoid present was myricetin $(20.54 \mathrm{mg} / \mathrm{L})$, followed by quercetin $(10.51 \mathrm{mg} / \mathrm{L})$ and luteolin $(5.79 \mathrm{mg} / \mathrm{L})$. In terms of phenolic acids, the main compound was protocatechuic acid $(6.58 \mathrm{mg} / \mathrm{L})$, followed by chlorogenic acid $(3.35 \mathrm{mg} / \mathrm{L})$ and caffeic acid $(2.41 \mathrm{mg} / \mathrm{L})$. It would be difficult to compare our findings with other studies because there is no standardization in individual phenolics quantification to extract volume or to pollen weight. In a study regarding the polyphenols from Tunisian pollen, it was reported that the main phenolic acids were cinnamic acids (coumarin and caffeic acid) and benzoic acids (gallic acids and vanillic acids), and the common flavonoids were epicatechin, catechin, rutin and quercetin [41]. Kostic et al. [42] reported in Serbian pollen the following major compounds: 5-O-caffeoylquinic acids $(2.54 \mathrm{mg} / \mathrm{kg}$ pollen) and caffeic acid $(2.16 \mathrm{mg} / \mathrm{kg})$ from the phenolic acids group, quercetin 3-O-galactoside $(112.86 \mathrm{mg} / \mathrm{kg})$ and isorhamnetin 3-O-glucoside $(14.46 \mathrm{mg} / \mathrm{kg})$ from the flavonols group and luteolin $(1.14 \mathrm{mg} / \mathrm{kg})$ and apigenin $(0.58 \mathrm{mg} / \mathrm{kg})$ from the flavones group. Zilic et al. [43] analyzed the composition of different flavonoids of pollen from red maize, white maize, yellow maize, blue maize, dark red maize, brown-red maize and sweet maize and observed that quercetin diglycoside was the most abundant one with concentration ranging between $31.22-45.49 \mathrm{mg} / \mathrm{kg}$, followed by isorhamnetin diglycoside (5.18-12.99 mg/kg), hyperoside glycoside (3.93-10.12 mg/kg) and rutin derivate $(3.65-6.56 \mathrm{mg} / \mathrm{kg})$.

Table 4. Phenolic profiles of the optimized pollen extract using the HPLC-DAD method.

\begin{tabular}{ccccc}
\hline Compound & $\begin{array}{c}\text { Molecular } \\
\text { Weight }\end{array}$ & $\begin{array}{c}\text { Wavelength } \\
(\mathbf{n m})\end{array}$ & $\begin{array}{c}\text { Retention } \\
\text { Time (min) }\end{array}$ & $\begin{array}{c}\text { Concentration } \\
\text { (mg/L) }\end{array}$ \\
\hline Gallic acid & 170.12 & 280 & 8.617 & ND \\
Protocatechuic acid & 154.12 & 280 & 15.833 & 6.58 \\
p-Hydroxybenzoic acid & 138.12 & 280 & 20.686 & 0.73 \\
Vanillic acid & 168.14 & 280 & 25.400 & 0.31 \\
Caffeic acid & 180.16 & 320 & 23.103 & 2.41 \\
Chlorogenic acid & 354.31 & 320 & 25.605 & 3.35 \\
p-Coumaric acid & 164.05 & 320 & 31.653 & 2.23 \\
Rosmarinic acid & 360.31 & 320 & 39.397 & ND \\
Myricetin & 318.24 & 320 & 43.225 & 20.54 \\
Luteolin & 286.24 & 320 & 49.691 & 5.79 \\
Quercetin & 302.24 & 320 & 50.173 & 10.51 \\
Kaempferol & 286.23 & 320 & 56.558 & ND \\
\hline
\end{tabular}




\subsection{FT-IR Spectroscopy}

The investigation of the functional groups of samples of crude pollen, defatted pollen, pollen extract (obtained at an ultrasonic amplitude of $100 \%$, solid/liquid ratio of $30 \mathrm{~g} / \mathrm{L}, 50{ }^{\circ} \mathrm{C}$ and $20 \mathrm{~min}$ extraction time) and pollen oil was made by means of FT-IR spectroscopy. The spectra of these four samples were recorded in absorbance mode in the mid-infrared region and are presented in Figure 2. The wide absorption band, observed at $3289.64 \mathrm{~cm}^{-1}$ and $3288.90 \mathrm{~cm}^{-1}$ for crude pollen and the defatted pollen sample, and at $3328.11 \mathrm{~cm}^{-1}$ for pollen extract was attributed to stretching vibrations of $\mathrm{O}-\mathrm{H}$ group and indicated the presence of water in the samples [44,45]. Moreover, the band at $1636.50 \mathrm{~cm}^{-1}$ (crude pollen) and $1634.77 \mathrm{~cm}^{-1}$ (defatted pollen) also corresponded to vibrations (bending) of the $\mathrm{O}-\mathrm{H}$ group [45]. The presence of these bands was expected, as previous studies reported that fresh pollen had moisture content between $7 \%$ and $30 \%$ [46]. In the region $3000-2850 \mathrm{~cm}^{-1}$, the peaks that were identified in the spectra of the samples were assigned to symmetric and asymmetric stretching of $\mathrm{C}-\mathrm{H}$ due to the presence of carbohydrates (mainly cellulose) and lipids [44,47]. For the pollen oil sample, the peaks in this region $\left(2921.71\right.$ and $2852.41 \mathrm{~cm}^{-1}$ ) were more pronounced, which was expected considering the nature of this sample. Furthermore, the peaks at 1736.32 and $1709.18 \mathrm{~cm}^{-1}$, which were identified only in the absorption spectra of the oil sample, corresponded to stretching vibrations of $\mathrm{C}=\mathrm{O}$ groups and were also due to the presence of lipids [48].

In the case of the crude and defatted pollen samples, the $\mathrm{O}-\mathrm{H}$ vibrations around $1630 \mathrm{~cm}^{-1}$ were part of a broad band between 1730 and $1530 \mathrm{~cm}^{-1}$ which comprises $\mathrm{C}=\mathrm{O}$ stretching due to both amide $\mathrm{I}$ and fatty acids, vibrations specific to $\mathrm{C}-\mathrm{N}$ stretching and $\mathrm{N}-\mathrm{H}$ deformation (amide II), and $\mathrm{C}=\mathrm{C}$ stretching in unsaturated lipids and aromatic structures [44,47]. The aromatic compounds most likely include $p$-coumaric acid and ferulic acid, which are two important components of sporopollenins [49]. Absorption peaks at $1730-1530 \mathrm{~cm}^{-1}$ were also observed for other bee products, showing that this spectral region was the most suitable for the quantification of sugars and organic acids in honey [50] and the identification of flavonoids and amino acids in crude propolis and propolis extract [21]. The range between 1200 and $500 \mathrm{~cm}^{-1}$ was considered the fingerprint region for pollen, where the $\mathrm{C}-\mathrm{O}$ and $\mathrm{C}-\mathrm{C}$ stretching indicated differences in the saccharide, protein and lipid composition of the samples. Bands around $1030 \mathrm{~cm}^{-1}$ in the spectra of crude pollen and defatted pollen were assigned to stretching vibrations of saccharides and proteins, while those around $800-700 \mathrm{~cm}^{-1}$ were characteristic only to saccharides. For the pollen extract, the presence of protein (amide I bands) was indicated by the peak at $1652.69 \mathrm{~cm}^{-1}$ and that of phenolic compounds by the peaks at 1448.88 and $1112.60 \mathrm{~cm}^{-1}$; the peak at $1015.27 \mathrm{~cm}^{-1}$ corresponding to stretching of the $\mathrm{C}-\mathrm{O}$ group might be determined by alcohol groups [21]. Finally, for pollen oil, the bands at $1464.19 \mathrm{~cm}^{-1}$ (deformation vibration of $\left.\mathrm{CH}_{2}\right), 1173.60 \mathrm{~cm}^{-1}$ (C-O stretching vibration) and $721.87 \mathrm{~cm}^{-1}\left(\mathrm{CH}_{2}\right.$ rocking), together with those around $1700 \mathrm{~cm}^{-1}$, confirmed the presence of the two main lipid groups of pollen (triglycerides and phospholipids) in this sample $[50,51]$.

\subsection{Fatty Acid Composition}

The pollen oil fatty acid methyl esters were determined using GC-MS, and from the 37 fatty acid methyl esters examined, only 21 were quantified, which are presented in Table 5 . The total concentration of fatty acids determined was $695.74 \mu \mathrm{g} \times \mathrm{g}^{-1}$ pollen, which is similar with the concentration of fatty acids reported by $\mathrm{Wu}$ et al. [15] for apricot bee pollen $\left(634.6 \mu \mathrm{g} \times \mathrm{g}^{-1}\right.$ pollen). The most abundant saturated acids were myristic acid $\left(159.1 \mu \mathrm{g} \times \mathrm{g}^{-1}\right.$ pollen $)$ and palmitic acid $\left(80.51 \mu \mathrm{g} \times \mathrm{g}^{-1}\right.$ pollen), while the most abundant mono-saturated acids were cis-14-pentadecenoic acid (106.61 $\mu \mathrm{g} \times \mathrm{g}^{-1}$ pollen) and trans-9-elaidic acid 18:1 $1 \omega \mathrm{t}\left(106.61 \mu \mathrm{g} \times \mathrm{g}^{-1}\right.$ pollen), respectively. Only one polyunsaturated acid was determined as linoleic acid $\left(11.63 \mu \mathrm{g} \times \mathrm{g}^{-1}\right.$ pollen). The oleic and palmitic acids play an important role in the nutrition of bees, while myristic, linoleic, linolenic acids are involved in the inhibition of growth of the spore-forming bacteria and other microbes that usually inhabit the hives [8]. 
Table 5. Fatty acids composition of pollen oil.

\begin{tabular}{|c|c|}
\hline Fatty Acid & Concentration $\left(\mu \mathrm{g} \times \mathrm{g}^{-1}\right.$ pollen $)$ \\
\hline Myristic acid 14:0 & 159.10 \\
\hline cis-14-Pentadecenoic acid 15:1 $\omega \mathrm{c}$ & 106.61 \\
\hline Palmitic acid $16: 0$ & 80.51 \\
\hline trans-9-Elaidic acid 18:1wt & 78.01 \\
\hline Hexanoic acid 6:0 & 46.93 \\
\hline Stearic acid 18:0 & 38.82 \\
\hline$z$-11-Tetradecenoic acid 14:1wc & 21.70 \\
\hline Pentadecanoic acid 15:0 & 21.20 \\
\hline Butyric acid 4:0 & 20.88 \\
\hline 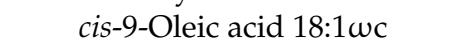 & 18.05 \\
\hline Palmitoleic acid 16:1 & 15.98 \\
\hline Myristoleic acid 14:1 & 14.57 \\
\hline Octanoic acid 8:0 & 14.13 \\
\hline Linoleic acid 18:2w6c & 11.63 \\
\hline Eicosanoic acid C:20 & 9.68 \\
\hline Decanoic acid 10:0 & 8.60 \\
\hline Tridecanoic acid 13:0 & 8.10 \\
\hline 11-Eicosenoic acid 20:1 & 6.66 \\
\hline Erucic acid 22:1 & 6.36 \\
\hline Heptadecanoaic acid 17:0 & 6.18 \\
\hline Lignoceric acid 24:0 & 2.03 \\
\hline
\end{tabular}

In a previous study on the fatty acids from maize pollen, it was observed that the abundant saturated acids were palmitic acid and henicosanoic acid, while the most abundant unsaturated fatty acids were oleic acid and elaidic acid; linoleic acid was the most abundant polyunsaturated fatty acid as observed in our case [42]. Belina-Aldemita et al. [52] observed that the most abundant fatty acids in Tetragonulabiroi Friese from polyfloral pollen lipids were palmitic acid $(28.51 \%), \alpha$-linolenic acid $(27.66 \%)$ and linoleic acid $(24.47 \%)$.

The fatty acids composition can vary from plant to plant, and in the same plant from part to part, and the same observation was made for saturated (SFAs), mono- (MUFAs) and polyunsaturated fatty acids (PUFAs). The World Health Organization [53] recommends that the ratio between UFAs and SFAs should be higher than 1.6 (WHO/FAO, 2003). The pollen oil analyzed contained $58.39 \%$ SFAs and $41.61 \%$ UFAs (39.83\% MUFAs and 1.78\% PUFAs), respectively; the ratio between UFAs and SFAs was 0.712 , which was below the ratio recommended. Kostic et al. [42] observed that the ratio of UFAs and SFAs ranged for fatty acid of maize pollen between 0.80 to 3.70 . 
A
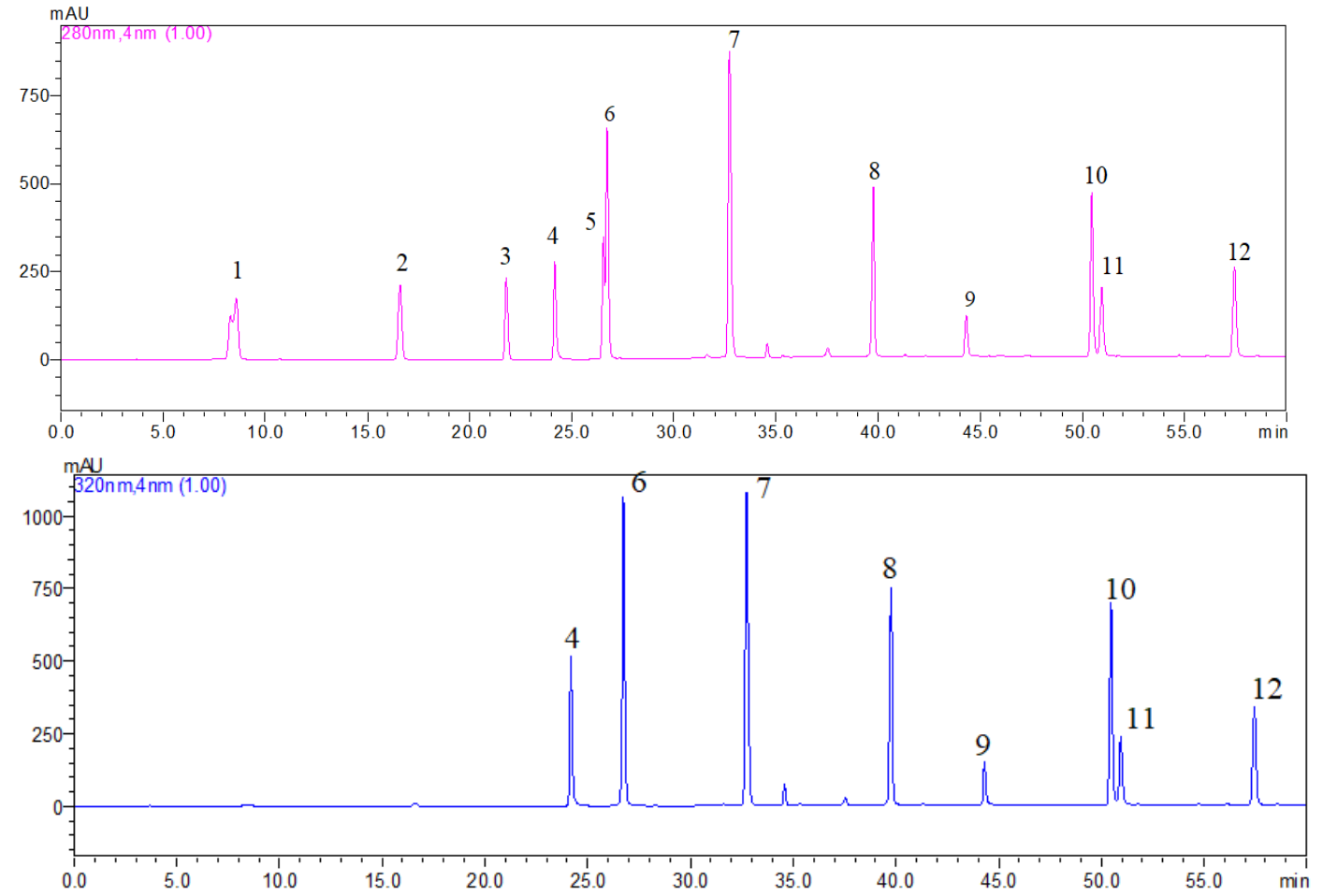

B
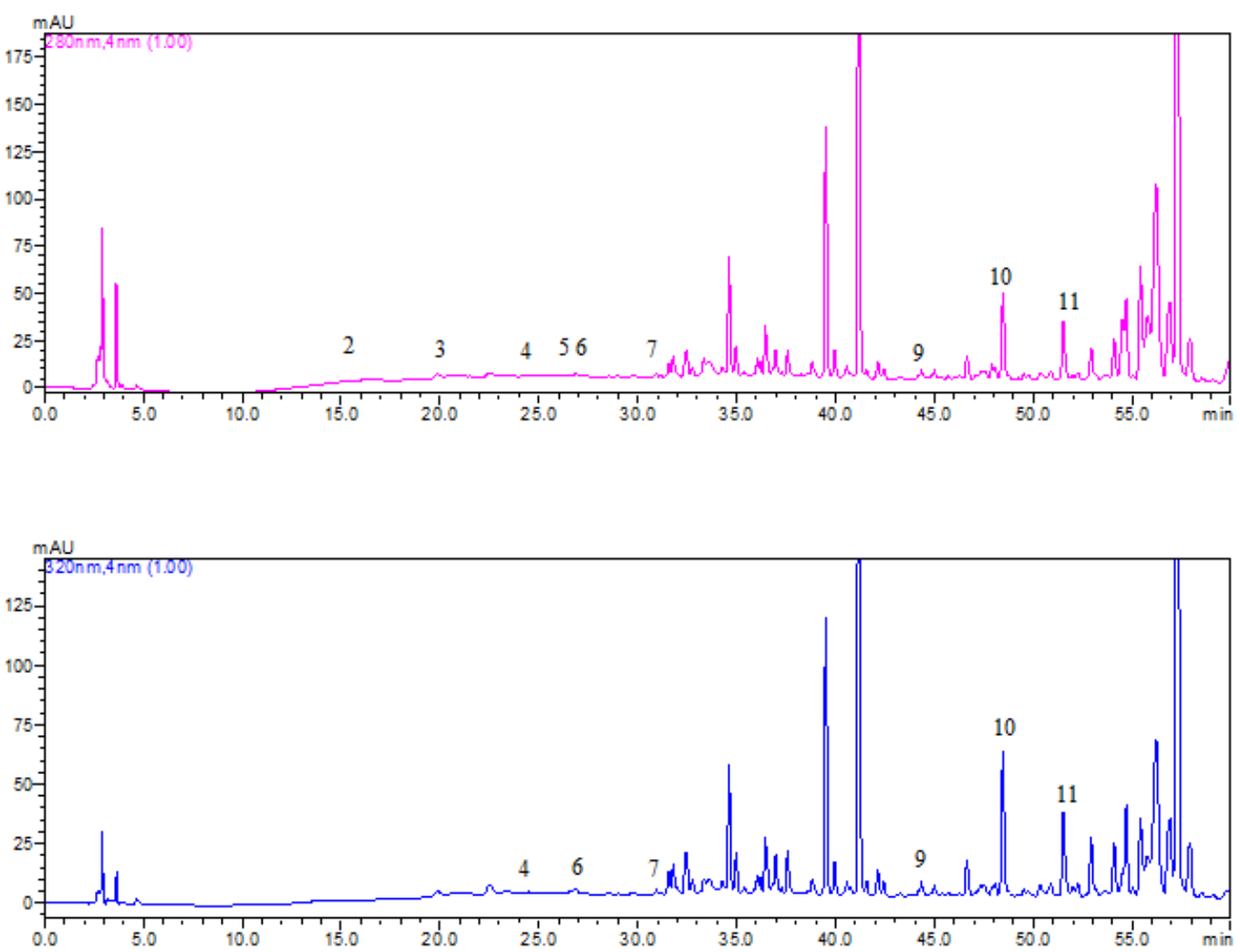

Figure 1. HPLC-DAD chromatogram at $280 \mathrm{~nm}$ and $320 \mathrm{~nm}$ for (A) standard (100 mg/L) for gallic acid-peak 1 (8.578 $\mathrm{min}$ ), protocatechuic acid-peak 2 (16.605 $\mathrm{min})$, -hydroxybenzoic acid-peak 3 (21.793 min), caffeic acid-peak 4 (24.175 min), vanillic acid-peak 5 (26.547 min), chlorogenic acid-peak 6 (26.733 min), p-coumaric acid-peak 7 (32.733 min), rosmarinic acid-peak 8 (39.767 min), myricetin-peak 9 (44.309 $\mathrm{min}$ ), luteolin-peak 10 (50.460 $\mathrm{min}$ ), quercetin-peak 11 (50.947 $\mathrm{min}$ ) and kaempferol-peak 12 (57.447 $\mathrm{min}$ ) and (B) methanoic extract pollen composition. 


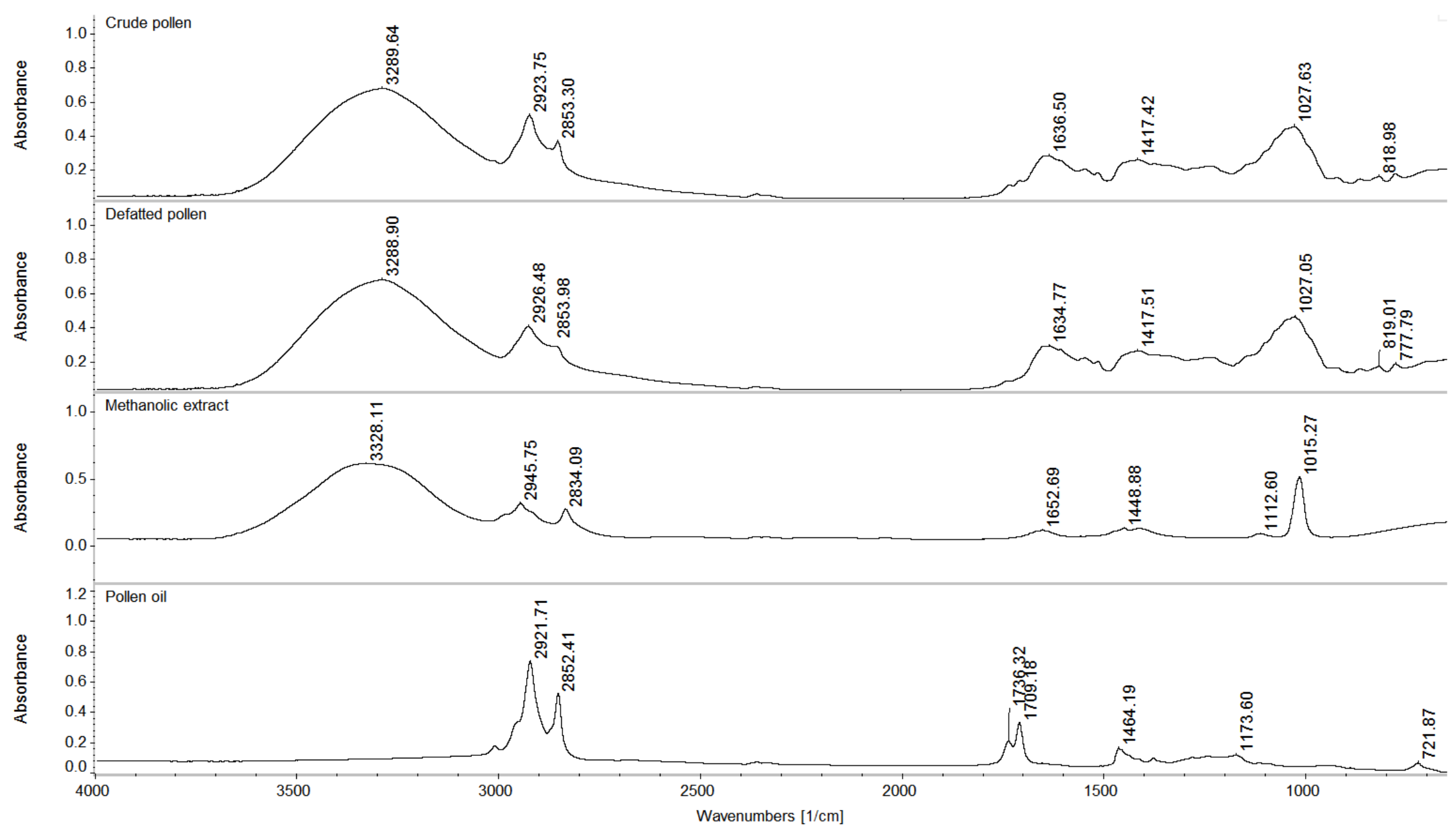

Figure 2. FT-IR spectra for crude pollen, defatted pollen, methanolic extract and pollen oil. 


\section{Conclusions}

In this study, an ultrasound-assisted extraction of bioactive compounds from pollen in different conditions (ultrasound amplitude, solid/liquid ratio, temperature and time) was investigated. The ultrasound amplitude and solid/liquid ratio had a statistically significant influence on the extraction yield, TPC and TFC; the extraction temperature influence was not statistically significant for the extraction yield and TPC, while the influence of time was negligible. The extraction yield ranged between $1.20 \%-1.48 \%$ in function of the extraction parameters applied. A Box-Behnken design was used for extraction modeling. The main flavonoid contained in the methanolic extract (of the flavonoids under study) was myricetin $(20.54 \mathrm{mg} / \mathrm{L})$, followed by quercetin $(10.51 \mathrm{mg} / \mathrm{L})$ and luteolin $(5.79 \mathrm{mg} / \mathrm{L})$. In the case of phenolic acids, the main compounds (of the phenolic acids under study) were protocatechuic acid $(6.58 \mathrm{mg} / \mathrm{L})$, chlorogenic acid $(3.35 \mathrm{mg} / \mathrm{L})$ and caffeic acid $(2.41 \mathrm{mg} / \mathrm{L})$. The extracted oil was analyzed in terms of fatty acids composition and myristic acid $\left(159.1 \mu \mathrm{g} \cdot \mathrm{g}^{-1}\right.$ pollen) and cis-14-pentadecenoic acid (106.61 $\mu \mathrm{g} \times \mathrm{g}^{-1}$ pollen) were found in the highest amounts in pollen oil. The optimum conditions were determined and were, as follows: 100\% amplitude of ultrasonic treatment, $30 \mathrm{~g} / \mathrm{L}$ solid/liquid ratio, $40.85^{\circ} \mathrm{C}$ and $14.30 \mathrm{~min}$, and resulted in the extraction of $366.1 \mathrm{mg} \mathrm{GAE} / \mathrm{L}$ of TPC, $592.2 \mathrm{mg} \mathrm{QE} / \mathrm{g}$ of TFC and a $1.92 \%$ extraction yield.

Author Contributions: Conceptualization, F.U.; data curation, F.D.; formal analysis, M.O.; funding acquisition, M.O.; investigation, M.O. and F.U.; methodology, F.D. and F.U.; project administration, M.O.; resources, F.D.; software, F.D.; validation, M.O. and F.U.; writing-original draft, F.D.; writing-review and editing, M.O. All authors have read and agreed to the published version of the manuscript.

Funding: This work was supported from contract no. 18PFE/16.10.2018 funded by ministry of Research and Innovation within Program 1: Development of national research and development system, Subprogram 1.2: Institutional Performance - RDI excellence funding projects.

Conflicts of Interest: The authors declare no conflict of interest.

\section{References}

1. Basim, E.; Basim, H.; Özcan, M. Antibacterial activities of Turkish pollen and propolis extracts against plant bacterial pathogens. J. Food Eng. 2006, 77, 992-996. [CrossRef]

2. Almeida-Muradian, L.; Pamplona, L.C.; Coimbra, S.; Barth, O.M. Chemical composition and botanical evaluation of dried bee pollen pellets. J. Food Compos. Anal. 2005, 18, 105-111. [CrossRef]

3. Nogueira, C.; Iglesias, A.; Feás, X.; Estevinho, L.M. Commercial Bee Pollen with Different Geographical Origins: A Comprehensive Approach. Int. J. Mol. Sci. 2012, 13, 11173-11187. [CrossRef] [PubMed]

4. Gardana, C.; Del Bo', C.; Quicazan, M.; Correa, A.R.; Simonetti, P. Nutrients, phytochemicals and botanical origin of commercial bee pollen from different geographical areas. J. Food Compos. Anal. 2018, 73, 29-38. [CrossRef]

5. Araújo, J.S.; Chambó, E.D.; Costa, M.A.P.D.C.; Da Silva, S.C.; De Carvalho, C.L.; Estevinho, L.M.; Da Silva, S.M.P.C.; De Carvalho, C.A.L. Chemical Composition and Biological Activities of Mono- and Heterofloral Bee Pollen of Different Geographical Origins. Int. J. Mol. Sci. 2017, 18, 921. [CrossRef]

6. Rzepecka-Stojko, A.; Stojko, J.; Kurek-Górecka, A.; Górecki, M.; Kabała-Dzik, A.; Kubina, R.; Moździerz, A.; Buszman, E. Polyphenols from Bee Pollen: Structure, Absorption, Metabolism and Biological Activity. Molecules 2015, 20, 21732-21749. [CrossRef]

7. Fatrcová-Šramková, K.; Nôžková, J.; Máriássyová, M.; Kačániová, M. Biologically active antimicrobial and antioxidant substances in theHelianthus annuusL. bee pollen. J. Environ. Sci. Heal. Part B 2015, 51, 176-181. [CrossRef]

8. Mărgăoan, R.; Mărghitaş, L.A.; Dezmirean, D.S.; Dulf, F.V.; Bunea, A.; Socaci, S.A.; Bobis, O. Predominant and Secondary Pollen Botanical Origins Influence the Carotenoid and Fatty Acid Profile in Fresh Honeybee-Collected Pollen. J. Agric. Food Chem. 2014, 62, 6306-6316. [CrossRef]

9. Marić, M.; Grassino, A.N.; Zhu, Z.; Barba, F.J.; Brnčić, M.; Brnčić, S.R. An overview of the traditional and innovative approaches for pectin extraction from plant food wastes and by-products: Ultrasound-, microwaves-, and enzyme-assisted extraction. Trends Food Sci. Technol. 2018, 76, 28-37. [CrossRef] 
10. Chemat, F.; Rombaut, N.; Meullemiestre, A.; Turk, M.; Perino, S.; Fabiano-Tixier, A.-S.; Abert-Vian, M. Review of Green Food Processing techniques. Preservation, transformation, and extraction. Innov. Food Sci. Emerg. Technol. 2017, 41, 357-377. [CrossRef]

11. Fernandez, M.L. Pectin. In Handbook of Dietary Fiber, 1st ed.; CRC Press: Boca Raton, FL, USA, 2001; Chapter 30; pp. 566-584. [CrossRef]

12. Chemat, F.; Rombaut, N.; Sicaire, A.-G.; Meullemiestre, A.; Fabiano-Tixier, A.-S.; Vian, M.A. Ultrasound assisted extraction of food and natural products. Mechanisms, techniques, combinations, protocols and applications. A review. Ultrason. Sonochemistry 2017, 34, 540-560. [CrossRef] [PubMed]

13. Moorthy, I.G.; Maran, J.P.; Ilakya, S.; Anitha, S.; Sabarima, S.P.; Priya, B. Ultrasound assisted extraction of pectin from waste Artocarpus heterophyllus fruit peel. Ultrason. Sonochemistry 2017, 34, 525-530. [CrossRef] [PubMed]

14. Dranca, F.; Oroian, M. Optimization of ultrasound-assisted extraction of total monomeric anthocyanin (TMA) and total phenolic content (TPC) from eggplant ( Solanum melongena L.) peel. Ultrason. Sonochemistry 2016, 31, 637-646. [CrossRef] [PubMed]

15. Wu, W.; Wang, K.; Qiao, J.; Dong, J.; Li, Z.; Zhang, H. Improving nutrient release of wall-disrupted bee pollen with a combination of ultrasonication and high shear technique. J. Sci. Food Agric. 2018, 99, 564-575. [CrossRef]

16. Yang, Y.; Zhang, J.-L.; Zhou, Q.; Wang, L.; Huang, W.; Wang, R. Effect of ultrasonic and ball-milling treatment on cell wall, nutrients, and antioxidant capacity of rose (Rosa rugosa) bee pollen, and identification of bioactive components. J. Sci. Food Agric. 2019, 99, 5350-5357. [CrossRef]

17. Escriche, I.; Juan-Borrás, M. Standardizing the analysis of phenolic profile in propolis. Food Res. Int. 2018, 106, 834-841. [CrossRef]

18. Popova, M.P.; Giannopoulou, E.; Bogdanov, S.; Tsvetkova, I.; Naydenski, C.; Marcazzan, G.L.; Sabatini, A.-G. Chemical characteristics of poplar type propolis of different geographic origin. Apidologie 2007, $38,306$. [CrossRef]

19. Palacios, I.; Lozano, M.; Moro, C.; D’Arrigo, M.; Rostagno, M.A.; Martinez, J.; García-Lafuente, A.; Guillamón, E.; Villares, A. Antioxidant properties of phenolic compounds occurring in edible mushrooms. Food Chem. 2011, 128, 674-678. [CrossRef]

20. Oroian, M.; Dranca, F.; Ursachi, F. Comparative evaluation of maceration, microwave and ultrasonic-assisted extraction of phenolic compounds from propolis. J. Food Sci. Technol. 2019, 57, 70-78. [CrossRef]

21. Oroian, M.; Ursachi, F.; Dranca, F. Influence of ultrasonic amplitude, temperature, time and solvent concentration on bioactive compounds extraction from propolis. Ultrason. Sonochem. 2020, 64, 105021. [CrossRef]

22. Dulf, F.V. Fatty acids in berry lipids of six sea buckthorn (Hippophae rhamnoides L., subspecies carpatica) cultivars grown in Romania. Chem. Central J. 2012, 6, 106. [CrossRef] [PubMed]

23. Maran, J.P.; Manikandan, S.; Nivetha, C.V.; Dinesh, R. Ultrasound assisted extraction of bioactive compounds from Nephelium lappaceum L. fruit peel using central composite face centered response surface design. Arab. J. Chem. 2017, 10, S1145-S1157. [CrossRef]

24. Da Porto, C.; Porretto, E.; Decorti, D. Comparison of ultrasound-assisted extraction with conventional extraction methods of oil and polyphenols from grape (Vitis vinifera L.) seeds. Ultrason. Sonochemistry 2013, 20, 1076-1080. [CrossRef] [PubMed]

25. Phan Van, M.; Tran Anh, V.; Tran Chi, H. Effect of ultrasound on extraction of polyphenol from the old tea leaves. Ann. Food Sci. Technol. 2017, 18, 1.

26. Yang, X.; Li, Y.; Li, S.; Oladejo, A.O.; Ruan, S.; Wang, Y.; Huang, S.; Ma, H. Effects of ultrasound pretreatment with different frequencies and working modes on the enzymolysis and the structure characterization of rice protein. Ultrason. Sonochemistry 2017, 38, 19-28. [CrossRef]

27. Dzah, C.S.; Duan, Y.; Zhang, H.; Wen, C.; Zhang, J.; Chen, G.; Ma, H. The effects of ultrasound assisted extraction on yield, antioxidant, anticancer and antimicrobial activity of polyphenol extracts: A review. Food Biosci. 2020, 35, 100547. [CrossRef]

28. Coussios, C.C.; Farny, C.H.; Ter Haar, G.; Roy, R. Role of acoustic cavitation in the delivery and monitoring of cancer treatment by high-intensity focused ultrasound (HIFU). Int. J. Hyperth. 2007, 23, 105-120. [CrossRef] 
29. Setyaningsih, W.; Saputro, I.E.; Carrera, C.; Ferreiro-González, M. Optimisation of an ultrasound-assisted extraction method for the simultaneous determination of phenolics in rice grains. Food Chem. 2019, 288, 221-227. [CrossRef]

30. De Oliveira, M.G.; De Almeida, P.H.; Oliveira, T.L.; Silva, L.D.S.; De Carvalho, F.S.; Alves, S.F.; Borges, L.L.; Dos Santos, P.A.; Da Silva, V.B.; De Paula, J.R. HPLC-PDA method validated for the determination of hibalactone in Hydrocotyle umbellata subterraneous parts and its ultrasound-assisted extraction optimization. Rev. Bras. de Farm. 2019, 29, 162-170. [CrossRef]

31. Pavlić, B.; Kaplan, M.; Bera, O.; Olgun, E.O.; Canli, O.; Milosavljević, N.; Antić, B.; Zeković, Z. Microwave-assisted extraction of peppermint polyphenols-Artificial neural networks approach. Food Bioprod. Process. 2019, 118, 258-269. [CrossRef]

32. Mustafa, A.; Turner, C. Pressurized liquid extraction as a green approach in food and herbal plants extraction: A review. Anal. Chim. Acta 2011, 703, 8-18. [CrossRef] [PubMed]

33. Vergara-Salinas, J.R.; Pérez-Jiménez, J.; Torres, J.L.; Agosin, E.; Pérez-Correa, J.R. Effects of Temperature and Time on Polyphenolic Content and Antioxidant Activity in the Pressurized Hot Water Extraction of Deodorized Thyme (Thymus vulgaris). J. Agric. Food Chem. 2012, 60, 10920-10929. [CrossRef] [PubMed]

34. Jovanović, A.A.; Đorđević, V.B.; Zdunić, G.; Pljevljakusic, D.; Šavikin, K.P.; Gođevac, D.M.; Bugarski, B.M. Optimization of the extraction process of polyphenols from Thymus serpyllum L. herb using maceration, heat- and ultrasound-assisted techniques. Sep. Purif. Technol. 2017, 179, 369-380. [CrossRef]

35. Dent, M.; Dragović-Uzelac, V.; Penić, M.; Brñić, M.; Bosiljkov, T.; Levaj, B. The effect of extraction solvents, temperature and time on the composition and mass fraction of polyphenols in dalmatian wild sage (Salvia officinalis L.) extracts. Food Technol. Biotechnol. 2013, 51, 84-91.

36. Miron, T.; Plaza, M.; Bahrim, G.; Ibanez, E.; Herrero, M. Chemical composition of bioactive pressurized extracts of Romanian aromatic plants. J. Chromatogr. A 2011, 1218, 4918-4927. [CrossRef] [PubMed]

37. Dranca, F.; Oroian, M. Total Monomeric Anthocyanin, Total Phenolic Content and Antioxidant Activity of Extracts from Eggplant (Solanum Melongena L.) Peel Using Ultrasonic Treatments. J. Food Process. Eng. 2015, 40, e12312. [CrossRef]

38. Lazar, L.; Talmaciu, A.I.; Volf, I.; Popa, V.I. Kinetic modeling of the ultrasound-assisted extraction of polyphenols from Picea abies bark. Ultrason. Sonochemistry 2016, 32, 191-197. [CrossRef]

39. Goula, A.M.; Thymiatis, K.; Kaderides, K. Valorization of grape pomace: Drying behavior and ultrasound extraction of phenolics. Food Bioprod. Process. 2016, 100, 132-144. [CrossRef]

40. Zhang, Z.-S.; Wang, L.-J.; Li, D.; Jiao, S.-S.; Chen, X.D.; Mao, Z.-H. Ultrasound-assisted extraction of oil from flaxseed. Sep. Purif. Technol. 2008, 62, 192-198. [CrossRef]

41. Daoud, A.; Malika, D.; Bakari, S.; Hfaiedh, N.; Mnafgui, K.; Kadri, A.; Gharsallah, N. Assessment of polyphenol composition, antioxidant and antimicrobial properties of various extracts of Date Palm Pollen (DPP) from two Tunisian cultivars. Arab. J. Chem. 2019, 12, 3075-3086. [CrossRef]

42. Kostić, A.Ž.; Mačukanović-Jocić, M.P.; Trifunović, B.Š.; Vukašinović, I.; Pavlović, V.; Pešić, M.B. Fatty acids of maize pollen-Quantification, nutritional and morphological evaluation. J. Cereal Sci. 2017, 77, 180-185. [CrossRef]

43. Žilić, S.; Vančetović, J.; Janković, M.; Maksimović, V.M. Chemical composition, bioactive compounds, antioxidant capacity and stability of floral maize (Zea mays L.) pollen. J. Funct. Foods 2014, 10, 65-74. [CrossRef]

44. Castiglioni, S.; Astolfi, P.; Conti, C.; Monaci, E.; Stefano, M.; Carloni, P. Morphological, Physicochemical and FTIR Spectroscopic Properties of Bee Pollen Loads from Different Botanical Origin. Molecules 2019, 24, 3974. [CrossRef] [PubMed]

45. Dos Anjos, O.M.S.; A Santos, A.J.; Dias, T.; Estevinho, L.M. Application of FTIR-ATR spectroscopy on the bee pollen characterization. J. Apic. Res. 2017, 26, 1-9. [CrossRef]

46. Thakur, M.; Nanda, V. Composition and functionality of bee pollen: A review. Trends Food Sci. Technol. 2020, 98, 82-106. [CrossRef]

47. Kasprzyk, I.; Depciuch, J.; Grabek-Lejko, D.; Parlinska-Wojtan, M. FTIR-ATR spectroscopy of pollen and honey as a tool for unifloral honey authentication. The case study of rape honey. Food Control. 2018, 84, 33-40. [CrossRef] 
48. Xu, X.-L.; Zheng, Y.-Z.; Chen, X.-C.; Zhu, F.-L.; Miao, X.-Q. Identification of cattail pollen, pine pollen and bee pollen by Fourier transform infrared spectroscopy and two-dimensional correlation infrared spectroscopy. J. Mol. Struct. 2018, 1167, 78-81. [CrossRef]

49. Jardine, P.; Abernethy, F.A.; Lomax, B.H.; Gosling, W.D.; Fraser, W. Shedding light on sporopollenin chemistry, with reference to UV reconstructions. Rev. Palaeobot. Palynol. 2017, 238, 1-6. [CrossRef]

50. Dos Anjos, O.M.S.; Campos, M.D.G.R.; Ruiz, P.C.; Antunes, P. Application of FTIR-ATR spectroscopy to the quantification of sugar in honey. Food Chem. 2015, 169, 218-223. [CrossRef]

51. Zimmermann, B.; Kohler, A. Infrared Spectroscopy of Pollen Identifies Plant Species and Genus as Well as Environmental Conditions. PLoS ONE 2014, 9, e95417. [CrossRef]

52. Belina-Aldemita, M.D.; Opper, C.; Schreiner, M.; D'Amico, S. Nutritional composition of pot-pollen produced by stingless bees (Tetragonula biroi Friese) from the Philippines. J. Food Compos. Anal. 2019, 82, 103215. [CrossRef]

53. WHO. Diet, nutrition and the prevention of chronic diseases. World Health Organ. Tech. Rep. Ser. 2003, 916, 1-149.

(C) 2020 by the authors. Licensee MDPI, Basel, Switzerland. This article is an open access article distributed under the terms and conditions of the Creative Commons Attribution (CC BY) license (http://creativecommons.org/licenses/by/4.0/). 